\title{
Pengaruh Pembiayaan Musyarakah Terhadap Profitabilitas Pada Bank Umum Syariah (Bus) Periode 2015-2017
}

\author{
Lucy Auditya dan Lufika Afridani \\ IAIN Bengkulu \\ $\underline{\text { luckyaudityabkl@gmail.com }}$
}

\begin{abstract}
The purpose of this study was to determine the effect of musyarakah financing on profitability in Sharia Commercial Banks in Indonesia for the 2015-2017 period and to find out how much influence musyarakah financing had on profitability in sharia commercial banks for the period 2015-2017. The limitation of the problem of this research is on the profitability of financial ratios ROA (Return On Assets) and ROE (Return On Equity). To disclose these issues in depth and thoroughly, researchers used a quantitative approach with secondary data collection techniques in the form of financial statements of each sharia bank for three consecutive years and provided quarterly financial reports, obtained by 5 Islamic banks to obtain 60 data. The data analysis technique used is simple linear regression using the SPSS version 16. Then the data is described, analyzed and discussed to answer the problems raised. From the results of the study it was found that musyarakah financing had a significant effect on ROA at alpha 5\%. This is evidenced by the significance value (Sig.) $(0.002)<(\alpha)$ 0.05. While musyarakah financing has no significant effect on ROE at alpha 5\%. This is evidenced by the significance value (Sig.) (0.669)> (a) 0.05 .
\end{abstract}

Keywords: Profitability, Financial Ratio ROA (Return On Asset) and ROE (Return On equity), Musyarakah Financing.

\section{PENDAHULUAN}

Pembiayaan musyarakah adalah transaksi penanaman dana dari dua atau lebih pemilik dana atau barang untuk menjalankan usaha tertentu sesuai syariah dengan pembagian hasil usaha antara kedua belah pihak berdasarkan nisbah yang disepakati, sedangkan pembagian kerugian berdasarkan proporsi modal masing-masing. Dalam akad musyarakah memiliki perbedaan pada modal, pengelolaan usahanya, dan pembagian keuntunganya. ${ }^{1}$

Lembaga keuangan akan dinilai baik kinerja usahanya apabila dapat dinilai dari suatu penilaian rasio keuntungannya.

1 Wangsawidjaja, Pembiayaan Bank Syariah, (Jakarta: PT. Gramedia Pustaka Utama,2012), h.78 
Rasio merupakan alat yang dinyatakan dalam artian relatif atau absolut untuk menjelaskan hubungan tertentu antara faktor satu dengan yang lainnya dari suatu laporan Financial. Untuk mengukur kemampuan lembaga usaha atau perusahaan dalam memperoleh laba secara keseluruhan dan tingkat efisiensi usaha, baik dari kegiatan operasional maupun non operasional digunakan faktor profitabilitas.

Adapun indikator yang digunakan untuk mengukur profitabiltas diantaranya Gros Profit Margin, Operating Profit Margin, Net Profit Margin, Return On Asset, Return On Equity, Return On Investment dan Earning Per Share. Profitabilitas atau dikenal dengan laba merupakan kemampuan suatu perusahaan untuk menghasilkan laba atau keuntungan selama periode tertentu (biasanya satu semester atau enam bulan, triwulan dan lain-lain), untuk melihat kemampuan perusahaan dalam beroperasi secara efisien. ${ }^{2}$ Profitabilitas yang tinggi dapat menunjukkan kinerja keuangan yang baik. Sebaliknya, jika profitabilitas yang dicapai rendah, mengindikasi kurang maksimalnya kinerja keuangan manajemen dalam menghasilkan laba. Jika profitabilitas yang rendah ini terus

\footnotetext{
${ }^{2}$ Asnaini, Evan Stiawan, Windi Asriani, Manajemen Keuangan, (Yogyakarta: Teras, 2012), h.96
}

dibiarkan akan berdampak pada rendahnya citra lembaga keuangan di mata masyarakat yang mengakibatkan kepercayaan masyarakat menjadi menurun. Dengan menurunnya kepercayaan masyarakat dapat menyebabkan proses penghimpunan dana mengalami bermasalah. ${ }^{3}$

Rasio profitabilitas akan menunjukkan kombinasi efek dari likuiditas, manajemen aktiva dan hutang pada hasilhasil operasi. Rasio profitabilitas ini mengukur efektifitas manajemen secara keseluruhan yang ditunjukan oleh besar kecilnya tingkat keuntungan yang diperoleh hubungannya dengan penjualan maupun investasi. ${ }^{4}$ Rasio profitabilitas mengukur kemampuan perusahaan untuk menghasilkan laba dengan menggunakan sumber-sumber yang dimiliki perusahaan, seperti aktiva, modal atau penjualan perusahaan. $^{5}$

Pada penelitian ini penulis hanya menggunakan dua indikator pengukuran profitabilitas yaitu ROA (Return on Assets) dan ROE (Return on Equity). ROA (Return on Asset) adalah rasio antara laba bersih terhadap total aktiva.

3 Kasmir, Analisa Laporan Keuangan, (Edisi Ke 3, Jakarta: Rajawali Pres,2012), h.196

${ }^{4}$ Irham Fahmi, Pengantar Manajemen Keuangan Teori Dan Soal Jawab, (Bandung: ALFABETA, 2016), h.80

${ }^{5}$ I Made Sudana, Manajemen Keuangan Perusahaan Teori \& Praktik, (Jakarta: Erlangga, 2012), h.22 
ROA (Return on Assets) merupakan pengukuran kemampuan perusahaan secara keseluruhan di dalam menghasilkan keuntungan dengan jumlah keseluruhan aktiva yang tersedia di dalam perusahaan. Semakin tinggi rasio ini, semakin baik keadaan suatu perusahaan. ${ }^{6}$ Sedangkan ROE (Return on Equity) adalah rasio laba bersih terhadap ekuitas. Rasio yang mengukur kemampuan perusahaan menghasilkan laba berdasarkan modal saham tertentu. Dibeberapa referensi disebut juga dengan rasio total asset turnover atau perputaran total asset. ${ }^{7}$
Berdasarkan data yang diperoleh di Otoritas Jasa Keuangan (OJK) pada bank umum syariah periode 2015-2017, fluktuasi nilai Profitabilitas ROA dan ROE tidak dipengaruhi oleh nilai pembiayaan musyarakah. Berdasarkan data awal yang disajikan terlihat bahwa Profitabilitas ROA dan ROE selalu mengalami fluktuasi dari tahun ke tahun, ada yang mengalami peningkatan dari tahun ketahunnya, namun adapula yang mengalami penurunan. Kenaikan dan penurunan tersebut dapat dilihat pada tabel berikut. 
Tabel. 1.1

Data Laporan Keuangan Bank Umum Syariah

Periode 2015-2017

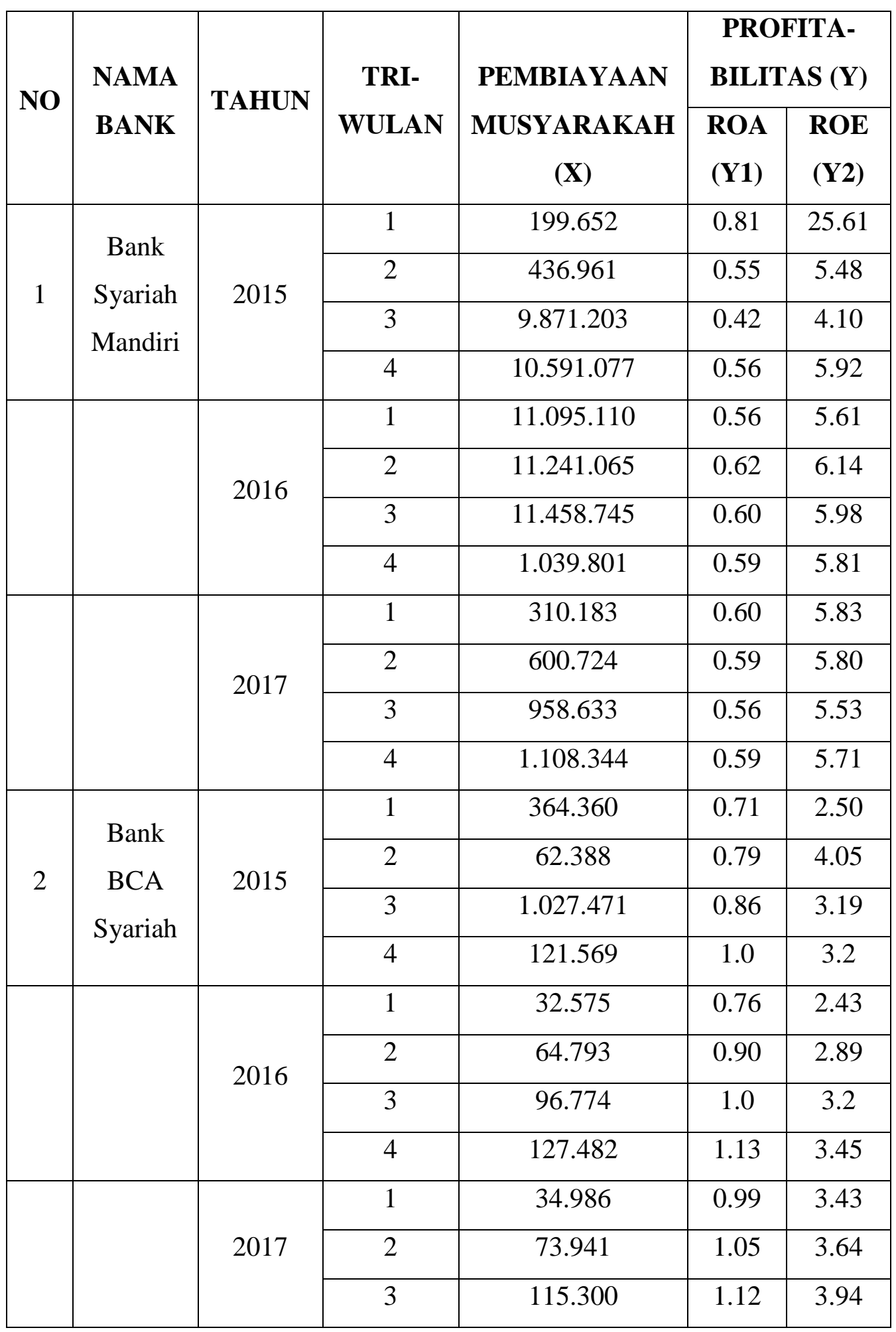




\begin{tabular}{|c|c|c|c|c|c|c|}
\hline & & & 4 & 163.810 & 1.17 & 4.28 \\
\hline \multirow{4}{*}{3} & \multirow{4}{*}{$\begin{array}{c}\text { Bank } \\
\text { Syariah } \\
\text { Bukopin }\end{array}$} & \multirow{4}{*}{2015} & 1 & 162.988 & 0.79 & 5.35 \\
\hline & & & 2 & 118.586 & 0.66 & 5.11 \\
\hline & & & 3 & 77.841 & 0.49 & 3.84 \\
\hline & & & 4 & 38.482 & 3.95 & 0.35 \\
\hline & & \multirow{4}{*}{2016} & 1 & 245.338 & 0.76 & 5.15 \\
\hline & & & 2 & 116.032 & 2.37 & 1.00 \\
\hline & & & 3 & 54.907 & 1.13 & 9.37 \\
\hline & & & 4 & 175.349 & 0.99 & 8.31 \\
\hline & & \multirow{4}{*}{2017} & 1 & 58.717 & 0.53 & 3.01 \\
\hline & & & 2 & 119.596 & 0.39 & 1.90 \\
\hline & & & 3 & 185.766 & 0.27 & 1.16 \\
\hline & & & 4 & 253.886 & 0.02 & 0.20 \\
\hline \multirow{4}{*}{4} & \multirow{4}{*}{$\begin{array}{c}\text { Bank } \\
\text { BRI } \\
\text { Syariah }\end{array}$} & \multirow{4}{*}{2015} & 1 & 117.418 & 0.53 & 6.07 \\
\hline & & & 2 & 92.871 & 0.78 & 7.16 \\
\hline & & & 3 & 99.399 & 0.80 & 6.72 \\
\hline & & & 4 & 513.496 & 0.76 & 8.20 \\
\hline & & & 1 & 101.086 & 0.99 & 7.51 \\
\hline & & 2016 & 2 & 170.495 & 1.03 & 7.89 \\
\hline & & 2010 & 3 & 219.815 & 0.98 & 7.51 \\
\hline & & & 4 & 193.940 & 0.95 & 7.40 \\
\hline & & & 1 & 128.160 & 0.65 & 5.49 \\
\hline & & 2017 & 2 & 255.403 & 0.71 & 6.01 \\
\hline & & 2011 & 3 & 391.847 & 0.82 & 6.90 \\
\hline & & & 4 & 528.286 & 0.51 & 4.10 \\
\hline & & & 1 & 37.084 & 1.20 & 9.29 \\
\hline 5 & Bank & 2015 & 2 & 74.595 & 1.30 & 10.10 \\
\hline 5 & BN1 & 2015 & 3 & 113.642 & 1.32 & 10.48 \\
\hline & syarıah & & 4 & 155.862 & 1.43 & 11.39 \\
\hline & & & 1 & 55.280 & 1.65 & 13.54 \\
\hline & & 2016 & 2 & 119.780 & 1.59 & 12.88 \\
\hline & & & 3 & 184.386 & 1.53 & 12.50 \\
\hline
\end{tabular}




\begin{tabular}{|l|l|l|l|l|l|} 
& & 4 & 254.817 & 1.44 & 11.94 \\
\hline \multirow{3}{*}{} & \multirow{3}{*}{2017} & 1 & 144.592 & 1.48 & 13.12 \\
\cline { 3 - 7 } & & 2 & 70.254 & 1.40 & 12.55 \\
\cline { 3 - 7 } & & 3 & 233.535 & 1.44 & 12.82 \\
\cline { 3 - 7 } & & 4 & 325.734 & 1.31 & 11.42 \\
\hline
\end{tabular}

Sumber: www.Syariahmandiri.co.id, www.bcasyariah.co.id, www.syariahbukopin.co.id, www.brisyariah.co.id, www.bnisyariah.co.id.

Berdasarkan data yang disajikan pada tabel diatas dapat dilihat bahwa semakin tinggi pembiayaan musyarakah yang disalurkan tidak selalu menjamin tingkat Profitabilitas ROA dan ROE mengalami kenaikan. Sehingga pertumbuhan pembiayaan musyarakah tidak selalu diikuti oleh pertumbuhan ROA dan ROE.

\section{Metode Penelitian}

Penelitian ini dilakukan pada bulan November 2017 sampai dengan Mei 2018. Penelitian ini dilakukan pada Bank Umum Syariah (BUS) dengan

\section{Profitabilitas}

\section{a. Pengertian Profitabilitas}

Profitabilitas merupakan hasil dari kebijaksanaan yang diambil oleh manajemen. Rasio keuntungan untuk mengukur seberapa besar tingkat keuntungan yang dapat diperoleh oleh perusahaan. Semakin besar tingkat keuntungan menunjukkan semakin baik

melihat laporan keuangan triwulan yang telah dipublikasi melalui website resminya pada Bank Umum Syariah yang terdaftar di Otoritas Jasa Keuangan (OJK) periode 2015-2017 (Jadwal Terlampir). Pendekatan penelitian ini adalah pendekatan kuantitatif dengan menggunakan populasi dan sampel. Sumber data dalam penelitian ini berupa data sekunder yang didapat atau dikumpulkan peneliti dari semua sumber yang sudah ada. Teknik pengumpulan data yang digunakan dalam penelitian ini adalah studi kepustakaan.

manajemen dalam mengelola perusahaan. ${ }^{8}$

Menurut Asnaini:

Profitabilitas atau dikenal dengan laba merupakan kemampuan suatu perusahaan untuk menghasilkan laba atau keuntungan selama periode tertentu (biasanya satu semester atau enam bulan, triwulan dan lain-lain), untuk melihat kemampuan

\footnotetext{
${ }^{8}$ Sutrisno, Manajemen Keuangan Teori, Konsep dan Aplikasi, ed.Rev (Yogyakarta:Ekonisia,2017), h.238
} 
perusahaan dalam beroperasi secara efisien. $^{9}$

Menurut K.R.Subramanyam:

Profitabilitas adalah hasil akhir dari sejumlah kebijakan dan keputusan yang dilakukan oleh perusahaan. Profitabilitas terdiri dari imbal hasil atas investasi untuk menilai imbalan keuangan kepada penyedia pendanaan ekuitas dan utang, kinerja operasi untuk mengevaluasi margin laba dari aktivitas operasi dan pendayagunaan asset (asset utilization) untuk menilai efektifitas dan intensitas asset dalam menghasilkan penjualan juga disebut perputaran (turnover). ${ }^{10}$

Rasio profitabilitas akan menunjukkan kombinasi efek dari likuiditas, manajemen aktiva dan hutang pada hasil-hasil operasi. Rasio profitabilitas ini mengukur efektifitas manajemen secara keseluruhan yang ditunjukan oleh besar kecilnya tingkat keuntungan yang diperoleh hubungannya dengan penjualan maupun investasi. ${ }^{11}$ Rasio profitabilitas mengukur kemampuan perusahaan untuk menghasilkan laba dengan menggunakan sumber-sumber yang dimiliki perusahaan,

\footnotetext{
${ }^{9}$ Asnaini, Evan Stiawan, Windi Asriani, Manajemen Keuangan, (Yogyakarta: Teras, 2012), h.96

${ }^{10}$ K.R.Subramanyam, Analisis Laporan Keuangan, (Jakarta: Salemba Empat, 2017), h.38

11 Irham Fahmi, Pengantar Manajemen Keuangan Teori Dan Soal Jawab, (Bandung: ALFABETA, 2016), h.80
}

seperti aktiva, modal atau penjualan perusahaan. $^{12}$

\section{b. Pengukuran Tingkat Profitabilitas}

Ada beberapa pengukuran terhadap profitabilitas perusahaan dimana masing-masing pengukuran dihubungkan dengan volume penjualan, total aktiva dan modal sendiri. Secara keseluruhan ketiga pengukuran ini akan memungkinkan seorang penganalisa untuk mengevaluasi tingkat earning dalam hubungannya dengan volume penjualan, jumlah aktiva dan investasi tertentu dari pemilik perusahaan. ${ }^{13}$

Disini perusahaan ditekankan pada profitabilitas, karena untuk dapat melangsungkan hidupnya. Suatu perusahaan haruslah berada dalam keadaan menguntungkan atau profitable. Tanpa adanya keuntungan akan sangat sulit bagi perusahaan untuk menarik modal dari luar. Para kreditur, pemilik perusahaan dan terutama sekali pihak manajemen perusahaan akan berusaha meningkatkan keuntungan ini, karena disadari betul betapa pentingnya arti keuntungan bagi masa depan perusahaan. $^{14}$

${ }^{12}$ I Made Sudana, Manajemen Keuangan Perusahaan Teori \& Praktik, (Jakarta: Erlangga, 2012), h.22

3 Lukman Syamsuddin, Manajemen Keuangan Perusahaan, (Jakarta: PT.Raja Grafindo Persada, 2013), h.59

14 Lukman Syamsuddin, Manajemen Keuangan Perusahaan...,h.59 


\section{c. Indikator Profitabilitas}

Adapun indikator yang digunakan untuk mengukur profitabilitas diantaranya: a. Gross Profit Margin, b.Operating Profit Margin, c. Net Profit Margin, d. Return On Assets, e. Return On Equity, f. Return On Investment, g. Earning Per Share.

Dalam penelitian ini penulis hanya menggunakan dua indikator pengukuran profitabilitas, yaitu:

1) ROA (Return on Assets) adalah rasio antara laba bersih terhadap total aktiva. ROA (Return on Assets) merupakan pengukuran kemampuan perusahaan secara keseluruhan di dalam menghasilkan keuntungan dengan jumlah keseluruhan aktiva yang tersedia di dalam perusahaan. Semakin tinggi rasio ini, semakin baik keadaan suatu perusahaan. $^{15}$

Rasio ini melihat sejauh mana investasi yang telah ditanamkan mampu memberikan pengembalian keuntungan sesuai dengan yang diharapkan. Dan investasi tersebut sebenarnya sama dengan asset perusahaan yang ditanamkan atau ditempatkan. Semakin tinggi tingkat laba maka akan semakin tinggi pula return on assetnya (ROA), karena hasil pengembalian terhadap

15 Lukman Syamsuddin, Manajemen Keuangan Perusahaan, (Jakarta: PT.Raja Grafindo Persada, 2013), h.63 jumlah harta dapat dipergunakan untuk mengukur efektifitas perusahaan dalam memanfaatkan seluruh sumber daya yang ada dalam perusahaan. ${ }^{16}$

ROA (Return On Asset) menunjukkan kemampuan perusahaan dengan menggunakan seluruh aktiva yang dimiliki untuk menghasilkan laba setelah pajak. Rasio ini penting bagi pihak manajemen untuk mengevaluasi efektivitas dan efisiensi manajemen perusahaan dalam mengelola seluruh aktiva perusahaan. Semakin besar ROA, berarti semakin efisien penggunaan aktiva perusahaan atau dengan kata lain dengan jumlah aktiva yang sama bisa dihasilkan laba yang lebih besar, dan sebaliknya. $^{17}$

2) ROE (Return On Equity) adalah rasio laba bersih terhadap ekuitas. Rasio yang mengukur kemampuan perusahaan menghasilkan laba berdasarkan modal saham tertentu. Dibeberapa referensi disebut juga dengan rasio total asset turnover atau perputaran total asset. Rasio ini mengkaji sejauh mana suatu perusahaan mempergunakan sumber

${ }^{16}$ Irham Fahmi, Manajemen Perbankan Konvesional \& Syariah, (Jakarta: Mitra Wacana Media, 2015), h.157

${ }^{17}$ I Made Sudana, Manajemen Keuangan Perusahaan Teori \& Praktik, (Jakarta: Erlangga, 2012), h.22 
daya yang dimiliki untuk mampu memberikan laba atas ekuitas. ${ }^{18}$

\section{ROE (Return on Equity)}

merupakan suatu pengukuran dari penghasilan (income) yang tersedia bagi para pemilik perusahaan (baik pemegang saham biasa maupun pemegang saham preferen) atas modal yang mereka investasikan di dalam perusahaan. Secara umum tentu saja semakin tinggi return atau penghasilan yang diperoleh semakin baik kedudukan pemilik perusahaan. ${ }^{19}$

Dalam ekuitas, investor tidak memiliki klaim atas payyofs yang telah ditentukan sebelumnya. Sebaliknya, investor ekuitas mencari dua payyofs utama (tidak pasti) pembayaran dividen dan kenaikkan modal. Kenaikkan modal menandakan perubahan nilai ekuitas, yang pada akhirnya ditentukan oleh dividen masa depan. ${ }^{20}$

ROE menunjukkan kemampuan perusahaan untuk menghasilkan laba setelah pajak dengan menggunakan modal sendiri yang dimiliki perusahaan. Rasio ini penting bagi pihak pemegang saham untuk mengetahui efektivitas dan efisiensi

${ }^{18}$ Irham Fahmi, Pengantar Manajemen Keuangan Teori Dan Soal Jawab, (Bandung: ALFABETA, 2016), h.82

19 Lukman Syamsuddin, Manajemen Keuangan Perusahaan, (Jakarta: PT.Raja Grafindo Persada, 2013), h.64

${ }^{20}$ K.R.Subramanyam, Analisis Laporan Keuangan, (Jakarta: Salemba Empat, 2017), h.43 pengelolaan modal sendiri yang dilakukan oleh pihak manajemen perusahaan. Semakin tinggi rasio ini berarti semakin efisien penggunaan modal sendiri yang dilakukan oleh pihak manajemen perusahaan.

Jadi dapat diambil kesimpulan bahwa Return On Asset (ROA) dan Return On Equity (ROE) adalah rasio profitabilitas untuk mengukur kemampuan perusahaan dalam menghasilkan laba bersih berdasarkan tingkat asset yang dimiliki perusahaan.

\section{Pembiayaan Musyarakah}

Menurut Abu Azam Al Hadi:

Musyarakah berasal dari kata syirkah. Syirkah menurut bahasa berarti alikhtilath (percampuran), yakni bercampurnya satu harta yang lain, sehingga tidak bisa dibedakan antara keduanya. Selanjutnya jumhul ulama mempergunakan kata syirkah untuk label satu transaksi tertentu, meski tidak ada percampuran dua bagian, karena terjadinya sebuah transaksi merupakan sebab terjadinya percampuran. ${ }^{21}$

Ada perbedaan pendapat di kalangan ulama dalam mendefinisikan syarikah secara syar'i (terminologi). Malikiyah mengatakan syarikah adalah pemberian wewenang kepada pihak-

\footnotetext{
${ }^{21}$ Abu Azam Al Hadi, Fikih Muamalah Kontemporer, (Depok: PT.RajaGrafindo Persada,2017), h.30
} 
pihak yang bekerja sama, artinya setiap pihak memberikan wewenang kepada partnernya atas harta yang dimiliki bersama, dengan masih absahnya wewenang atas harta masing-masing. Hanabilah mengatakan syarikah adalah percampuran dalam kepemilikan dan wewenang. Syafi'iyah mengatakan syarikah adalah tertetapnya hak kepemilikan bagi dua pihak atau lebih. Hanafiyah berkata, syarikah adalah transaksi yang dilakukan dua pihak dalam hal permodalan dan keuntungan. Definisi ini paling tepat karena mengungkapkan hakekat syarikah yang notabene sebuah transaksi. ${ }^{22}$

\section{Fungsi Pembiayaan}

Keberadaan Bank Syariah yang menjalankan pembiayaan berdasarkan prinsip syariah bukan hanya untuk mencari keuntungan dan meramaikan bisnis perbankan di Indonesia, tetapi juga untuk menciptakan lingkungan bisnis yang aman, diantaranya: 1) Memberikan pembiayaan dengan prinsip syariah yang menerapkan sistem bagi hasil yang tidak memberatkan debitur, 2) Membantu kaum dhu'afa yang tidak tersentuh oleh bank konvensional karena tidak mampu memenuhi persyaratan yang ditetapkan oleh bank konvensional, 3) Membantu masyarakat ekonomi lemah yang selalu

22 Heri Sudarsono, Bank dan ..., h.393 dipermainkan oleh renternir dengan membantu melalui pendanaan untuk usaha yang dilakukan. ${ }^{23}$

\section{Prinsip-prinsip}

Pembiayaan

\section{Musyarakah}

Adapun prinsip-prinsip

Pembiayaan Musyarakah diantaranya adalah: 1) Proyek atau kegiatan usaha yang akan dikerjakan feasible dan tidak bertentangan dengan syariah, 2) Pihakpihak yang turut dalam kerja sama memasukkan dana musyarakah dengan ketentuan: a) Dapat berupa uang tunai atau assets yang likuid, b) Dana yang terhimpun bukan lagi milik perorangan, tetapi menjadi dana usaha. ${ }^{24}$

Musyarakah dalam teknis perbankan didefinisikan sebagai akad kerja sama pembiayaan antara Islamic Banking, atau beberapa lembaga keuangan secara bersama-sama, dan nasabah untuk mengelolah suatu kegiatan usaha. Masing-masing memasukkan penyertaan dana sesuai porsi yang disepakati. Pengelolaan kegiatan usaha, dipercayakan kepada nasabah. Selaku pengelola, nasabah wajib menyampaikan laporan berkala mengenai perkembangan usaha kepada bank-bank sebagai pemilik dana.

\footnotetext{
23 Yusuf Ayus Ahmad dan Abdul Aziz, Manajemen Operasional Bank Syariah, (Cirebon:STAIN Press,2012), h.68

${ }^{24}$ M.Yazid Afandi, Fiqh Muamalah dan Implementasinya..., h.122
} 
Rukun dan Syarat Pembiayaan Musyarakah

Rukun dari akad Musyarakah yang harus dipenuhi dalam trnsaksi ada beberapa, yaitu: a) Pelaku akad (para mitra usaha), b) Objek akad (modal/mal, kerja/dharabah, keuntungan/ribh), c) Perjanjian yang dilakukan kedua belah pihak (shighat/ ijab dan qabul).

Musyarakah merupakan hubungan yang dibentuk oleh para mitra melalui kontrak akad yang disepakati bersama, maka otomatis empat syarat akad yaitu: a) Syarat berlakunya akad (in'iqod), b) Syarat sahnya akad (shihah), c) Syarat terealisasinya akad (nafadz), d) Syarat lazim yang harus dipenuhi. ${ }^{25}$

\section{Fatwa DSN Terkait Dengan Pembiayaan Musyarakah}

Fatwa mengenai pembiayaan Musyarakah No: 08/DSN-MUI/IV/2000 mempunyai beberapa ketentuan, yaitu:

a. Pernyataan ijab qabul harus dinyatakan oleh para pihak untuk menunjukkan kehendak mereka dalam mengadakan kontrak (akad), dengan memperlihatkan hal-hal berikut: (1) Penawaran dan penerimaan harus eksplisit menunjukkan tujuan kontrak (akad). (2) Penerimaan dari penawaran

\footnotetext{
${ }^{25}$ Muhammad Syafi'i Antonio, Bank Syariah dari Teori ke Praktik, h.94
}

dilakukan secara kontrak. (3) Akad dituangkan secara tertulis, melalui korespondensi, atau dengan menggunakan cara-cara komunikasi modern.

b. Pihak-pihak yang berkontrak harus cakap hukum, dan memperhatikan hal-hal berikut: (1) Kompeten dalam memberikan atau diberikan kekuasaan perwakilan. (2) Setiap mitra harus menyediakan dana dan pekerjaan, dan setiap mitra melaksanakan kerja sebagai wakil.(3) Setiap mitra memiliki hak untuk mengatur aset musyarakah dalam proses bisnis norma. (4) Setiap mitra memberi wewenang kepada mitra yang lain untuk mengelola aset dan masing-masing dianggap telah diberi wewenang untuk melakukan aktivitas musyarakah dengan memperhatikan kepentingan mitranya, tanpa melakukan kelalaian dan kesalahan yang disengaja. (5) Seorang mitra tidak diizinkan untuk mencairkan atau menginvestasikan dana untuk kepentingannya sendiri.

c. Objek akad (modal, keuntungan dan kerugian)

1) Modal

a) Modal yang diberikan harus uang tunai, emas, perak, atau yang nilainya sama. Modal dapat terdiri 
dari aset perdagangan, seperti barngbarang, properti dan sebagainya. Jika modal bentuk aset, harus terlebih dahulu dinilai dengan tunai dan disepakati para mitra.

b) Para pihak tidak boleh meminjam, meminjamkan. Menyumbangkan atau menghadiahkan modal musyarakah kepada pihak lain, kecuali atas dasar kesepakatan.

c) Pada prinsipnya, dalam pembiayaan musyarakah tidak ada jaminan, namun untuk menghindari terjadinya penyimpangan, LKS dapat meminta jaminan.

2) Kerja

a) Partisipasi para mitra dalam pekerjaan merupakan dasar pelaksanaan musyarakah akan tetapi, kesamaan porsi kerja bukanlah merupakn syarat. Seorang mitra boleh melaksanakan kerja lebih banyak dari yang lainnya, dan dalam hal ini ia boleh menuntut bagian keuntungan tambahan bagi dirinya.

b) Setiap mitra melaksanakan kerja dalam musyarakah atas nama pribadi dan wakil dari mitranya. Kedudukan masing-masing dalam organisasi kerja harus dijelaskan dalam kontrak.

3) Keuntungan a) Keuntungan harus dikuantitifikasi dengan jelas untuk menghindarkan perbedaandan sengketa pada waktu alokasi keuntungan atau penghentian musyarakah. Setiap keuntungan mitra harus dibagikan secara proporsional atas dasar seluruh keuntungan dan tidak ada jumlah yang dintentukan di awal yang ditetapkan bagi seorang mitra. Seorang mitra boleh mengusulkan bahwa jika keuntungan melebihi jumlah terntentu, kelebihan atau persentase itu diberikan kepadanya.

b) Sistem pembagian keuntungan harus tertuang dengan jelas dalam akad.

\section{4) Kerugian}

Kerugian harus dibagi diantara para mitra secara proporsional menurut saham masing-masing dalam modal.

a) Biaya operasional dibebankan pada modal bersama.

b) Jika salah satu pihak tidak menunaikan kewajibannya atau jika terjadi perselisihan diantara para pihak, maka penyelesaiannya dilakukan melalui Badan Arbitrasi Syariah setelah tidak tercapai kesepakatan melalui musyawarah. $^{26}$

26 Abu Azam Al Hadi, Fikh Muamalah Kontemporer, (Depok: PT RajaGrafindo Persada, 2017), h. 45-47 


\section{Pengaruh Pembiayaan Musyarakah terhadap Profitabilitas}

Bank Umum Syariah dapat mendorong dan mempercepat kemajuan ekonomi dengan melakukan kegiatan perbankan sesuai dengan prisnsip-prinsip syariah. Salah satu produk yang ada pada Bank Umum Syariah adalah pembiayaan musyarakah dengan sistem bagi hasil yang bertujuan untuk mendapatkan keuntungan. Masing-masing pihak menyertakan modalnya dan ikut mengelola usaha tersebut. Keuntungan dan kerugian akan dibagi berdasarkan persentase penyertaan modalnya. Pengaruh yang ditimbulkan pada pembiayaan musyarakah jika terjadi kerugian maka resiko yang ditanggung pihak bank lebih besar, karena penyertaan modal dan penanggungan kerugian akan dibagi oleh masing-masing pihak. Jadi, apabila pendapatan musyarakah semakin besar maka dapat meningkatkan profitabilitas. Hal ini menunjukkan bahwa pembiayaan musyarakah berpengaruh terhadap profitabilitas. $^{27}$

${ }^{27}$ Nuril Wahidah Risqi, "Analisis Pengaruh Pembiayaan Mudharabah, Muusyarakah, dan Ijarah Terhadap Profitabilitas Bank Syariah Di Indonesia (Studi Empiris Pada Bank Umum Syariah Yang Listing Di Otoritas Jasa Keuangan Periode 2010-2016)", (Skripsi, Fakultas Ekonomi Universitas Islam Malang,2012)
Keuntungan dari pembiayaan musyarakah tersebut dapat diukur dengan melihat ROA (Return on Asset) dan ROE (Return on Equity) dari Bank Umum Syariah. Hasil dari kegiatan pembiayaan yang dilakukan Bank Syariah akan memperoleh keuntungan yang berpengaruh pada bertambahnya jumlah pendapatan. Keuntungan yang diterima dari pembiayaan musyarakah brasal dari mark up yang telah disepakati anatara nasabah dan bank, sedangkan pada pembiayaan musyarakah, keuntungan yang dihasilkan berdasarkan kesepakatan besarnya nisbah. Oleh sebab itu, jika Bank Syariah dapat mengelola berbagai macam pembiayaan dengan baik, maka akan sangat mempengaruhi profitabilitas yang dimiliki suatu Bank Syariah. Karena besarnya pendapatan yang diperoleh dari pengelolaan asset (pembiayaan) yang dimiliki suatu Bank dapat menjadi indikator didalam meningkatkan laba Bank Syariah itu sendiri.

Kualitas investasi pada musyarakah dapat didasarkan atas tingkat kesesuaian antar realisasi bagi hasil dan proyeksinya. Porsi yang diterima bank tergantung besar keuntungan yang diperoleh nasabah dikaitkan persentase sesuai perjanjian atau akad diawal. Penyebab utama dari risiko kredit adalah 
penilaian kredit yang kurang cermat dan lemahnya antsipasi terhadap kemungkinan resiko usaha yang dibiayai. Pendapatan musyarakah memiliki pengaruh besar terhadap perubahan

\section{Hipotesis}

Hipotesis ini merupakan jawaban yang bersifat sementara terhadap permasalahan penelitian, sampai terbukti melalui data-data yang terkumpul. Berdasarkan perumusan masalah yang ada, maka hipotesis penelitian yaitu:

1.H0: Tidak terdapat pengaruh yang signifikan antara pembiayaan Musyarakah terhadap Profitabilitas ROA (Return On Asset) pada Bank Umum Syariah yang dipublikasikan oleh Otoritas Jasa Keuangan (OJK).

Ha: Terdapat pengaruh yang signifikan antara pembiayaan Musyarakah terhadap Profitabilitas ROA (Return On Asset) pada Bank Umum Syariah Yang dipublikasikan oleh Otoritas Jasa Keuangan (OJK).

\section{PEMBAHASAN}

\section{Pembiayaan Musyarakah} berpengaruh signifikan terhadap ROA periode 2015-2017.

Hasil perhitungan regresi menunjukan bahwa pembiayaan musyarakah berpengaruh signifikan terhadap ROA pada alpha 5\%. Hal tersebut dibuktikan nilai signifikansi (Sig.) $(0,002)<(\alpha)$ tingkat profitabilitas. Artinya, perubahan yang terjadi pada pendapatan musyarakah memiliki pengaruh besar terhadap profitabilitas.

2. H0: Pembiayaan Musyarakah berpengaruh signifikan terhadap Profitabilitas ROE (Return On Equity) pada Bank Umum Syariah Yang dipublikasikan oleh Otoritas Jasa Keuangan (OJK).

Ha: Pembiayaan Musyarakah berpengaruh signifikan terhadap Profitabilitas ROE (Return On Equity) pada Bank Umum Syariah Yang dipublikasikan oleh Otoritas Jasa Keuangan (OJK).

Dengan demikian, hipotesis penulis semakin baik pembiayaan musyarakah maka akan semakin baik pula profitabilitas pada Bank Umum Syariah Di Indonesia Periode 2015-2017.

0,05. Hasil perhitungan tersebut menunjukan bahwa peningkatan dan penurunan pembiayaan musyarakah dipengaruhi dengan adanya penurunan dan peningkatan dari jumlah keseluruhan aktiva (Return On Asset) ROA. Pengaruh yang ditimbulkan pada pembiayaan musyarakah jika terjadi kerugian maka resiko yang ditanggung pihak bank lebih 
besar, karena penyertaan modal dan penanggungan kerugian akan dibagi oleh masing-masing pihak. Jadi, apabila pendapatan musyarakah semakin besar maka dapat meningkatkan jumlah keseluruhan aktiva. Hal ini menunjukkan bahwa pembiayaan musyarakah berpengaruh terhadap jumlah keseluruhan aktiva (Return On Asset) ROA.

\section{Pembiayaan Musyarakah tidak}

berpengaruh signifikan terhadap

ROE periode 2015-2017.

Hasil perhitungan regresi menunjukan bahwa pembiayaan musyarakah tidak berpengaruh signifikan terhadap ROE pada alpha 5\%. Hal tersebut dibuktikan nilai signifikansi (Sig.) $(0,669)>(\alpha)$ 0,05. Hasil perhitungan tersebut menunjukan bahwa pembiayaan musyarakah tidak berpengaruh terhadap efesiensi kegiatan operasional (Return On Equity) ROE. Artinya banyak sedikitnya pembiayaan yang disalurkan dengan akad musyarakah ke masyarakat, tidak akan mempengaruhi return on equity Bank Umum Syariah. Pembiayaan musyarakah yang produk inti perbankan syariah dengan prinsip bagi hasil yang keuntungannya dibagi diantara mitra secara proporsional sesuai modal yang disetor atau sesuai nisbah yang disepakati antara bank dengan mitra, dan biasanya pembiayaan untuk jangka menengah atau panjang sehingga belum memberikan kontribusi yang cukup signifikan terhadap laba. Hal ini menyebabkan pembiayaan musyarakah tidak berpengaruh terhadap efesiensi kegiatan operasional (Return On Equity) ROE.

\section{Besarnya Pengaruh Pembiayaan} Musyarakah Terhadap Profitabilitas pada Bank Umum Syariah di Indonesia Periode 2015-2017.

Berdasarkan hasil koefisien determinasi adjusted $R^{2}$ (Adjusted $R$ Square) adalah sebesar 0,163 hal itu berarti bahwa interprestasi koefisien determinasi sangat rendah. Jadi besarnya pengaruh pembiayaan musyarakah secara parsial berpengaruh signifikan terhadap ROA sebesar $16,3 \%$, sedangkan sisanya $83,7 \%$ dipengaruhi oleh faktor lain diluar penelitian ini. Sedangkan adjusted $R^{2}$ (Adjusted $R$ Square) untuk ROE adalah 0,003 maka dalam penelitian ini tidak bisa dihitung koefisien determinasinya karena tidak terdapat pengaruh.

\section{Kesimpulan}

Berdasarkan hasil penelitian dan uji statistik yang dilakukan terkait pengaruh pembiayaan musyarakah terhadap profitabilitas pada Bank Umum Syariah di Indonesia periode 2015-2017, 
maka dapat diambil kesimpulan sebagai berikut:

1. Pembiayaan Musyarakah berpengaruh signifikan terhadap ROA periode 2015-2017 yang dibuktikan dengan nilai signifikansi lebih kecil dari pada alpha (Sig.) $(0,002)<(\alpha) 0,05$.

2. Pembiayaan Musyarakah tidak berpengaruh signifikan terhadap ROE periode 2015-2017.

3. Berdasarkan hasil koefisien determinasi adjusted $R^{2}$ (Adjusted $R$ Square) adalah sebesar 16,3\%, sedangkan sisanya $\quad 83,7 \%$ dipengaruhi oleh faktor lain diluar penelitian ini. Sedangkan adjusted $R^{2}$ (Adjusted $R$ Square) untuk ROE adalah 0,003 maka dalam penelitian ini tidak bisa dihitung koefisien determinasinya karena tidak terdapat pengaruh.

\section{DAFTAR PUSTAKA}

Affandi, Yazid. Fiqh Muamalah dan Implementasinya Dalam Lembaga Keuangan Syari'ah. Yogyakarta: Logung Printika.2012.

Antonio, Syafi'i Muhammad. Bank Syariah dari teori ke praktik. Jakarta: Gema Insani.2012.
Asnaini, Evan Stiawan, Windi Asriani, Manajemen Keuangan. Yogyakarta: Teras.2012.

Fahmi, Irham. Manajemen Perbankan Konvesional \& Syariah. Jakarta: Mitra Wacana Media.2015.

Fahmi, Irham. Pengantar Manajemen Keuangan Teori Dan Soal Jawab. Bandung: ALFABETA.2016.

Hadi Al, Azam Abu. Fikih Muamalah Kontemporer. Depok: PT.RajaGrafindo Persada.2017.

http://www.bcasyariah.co.id.(diakses pada tanggal 13 April 2018)

http://www.bnisyariah.co.id.(diakses pada tanggal 13 April 2018)

http://www.brisyariah.co.id.(diakses pada tanggal 13 April 2018)

http://www.syariahbukopin.co.id.(diakses pada tanggal 13 April 2018)

http://www.syariahmandiri.co.id.(diakses pada tanggal 13 April 2018) 
Kasmir. Analisa Laporan Keuangan Edisi Ke 3. Jakarta: Rajawali Pres.2012.

Kurniawan Heri, Yamin Sofyan. SPSS Complate Teknik analisis Statistik Terlengkap dengan Software SPSS. Jakarta: Jagakarsa.2012.

Pesulima, Buce. Analisis Pengaruh Pembiayaan Mudharabah dan Musyarakah Terhadap Profitabilitas (Studi Pada Bank Syariah Yang Terdaftar Pada Otoritas Jasa Keuangan, Jurnal Indonesia: Jurnal Ekonomi Dan Bisnis. Vol.19.No.2.September 2016.

Subramanyam K.R. Analisis Laporan Keuangan. Jakarta: Salemba Empat.2017.
Sudana, Made I. Manajemen Keuangan Perusahaan Teori dan Praktik. Jakarta: Erlangga.2012.

Sudarsono, Heri. Bank dan Lembaga Keuangan Syari'ah Deskripsi dan Ilustrasi Edisi 3. Yogyakarta: Ekonisia.2012.

Sutrisno, Manajemen Keuangan Teori, Konsep dan Aplikasi, ed.Rev. Yogyakarta:Ekonisia.2017.

Syamsuddin, Lukman. Manajemen Keuangan Perusahaan. Jakarta: PT.Raja Grafindo Persada.2013.

Wangsawidjaja, Pembiayaan Bank Syariah. Jakarta: PT. Gramedia Pustaka Utama.2012. 